\title{
ChemComm
}

Check for updates

Cite this: Chem. Commun., 2019, 55,4789

Received 28th December 2018, Accepted 26th February 2019

DOI: $10.1039 / \mathrm{c} 8 \mathrm{cc} 10254 f$

rsc.li/chemcomm

\section{Electrodeposition of indium from non-aqueous electrolytes $\dagger$}

\author{
Wouter Monnens, (DD ${ }^{a}$ Clio Deferm, (D) ${ }^{b}$ Jeroen Sniekers, ${ }^{b}$ Jan Fransaer (D) a and \\ Koen Binnemans (D) *b
}

The electrochemical behaviour and deposition of indium in electrolytes composed of $0.4 \mathrm{~mol} \mathrm{dm}^{-3} \ln \left(\mathrm{Tf}_{2} \mathrm{~N}\right)_{3}$ and $0.4 \mathrm{~mol} \mathrm{dm}^{-3}$ $\mathrm{InCl}_{3}$ in the solvents 1,2-dimethoxyethane and poly(ethylene glycol) (average molecular mass of $0.400 \mathrm{~kg} \mathrm{~mol}^{-1}, \mathrm{PEG} 400$ ) was investigated. Indium( (I) was identified as the intermediate species that disproportionated to indium(III) and indium( 0 ) nanoparticles. The presence of nanoparticles was verified by TEM analysis. SEM analysis showed that deposits obtained at room temperature from 1,2-dimethoxyethane were rough, while spherical structures were formed in PEG400 at $160{ }^{\circ} \mathrm{C}$.

Indium is a technologically important metal that finds application in flat panel display devices as transparent indium tin oxide (ITO) electrodes, in various binary compound semiconductors, and in copper (indium, gallium) selenide (CIGS) solar cells. ${ }^{1,2}$ Electrodeposition of indium from aqueous electrolytes has been extensively studied, but the co-evolution of hydrogen gas leads to low current efficiencies. ${ }^{3-5}$ Electrodeposition of indium has also been investigated from non-aqueous electrolytes such as ionic liquids, ${ }^{6-9}$ deepeutectic solvents ${ }^{10-13}$ and molten salts ${ }^{14,15}$ for electrowinning and formation of indium compounds. However, ionic liquids and deepeutectic solvents are often very viscous at ambient temperatures, whereas the use of high-temperature molten salts consumes a lot of energy. Electrodeposition experiments on tetrabutylammonium tetrachloroindate(III) dissolved in dichloromethane gave indium particles rather than indium coatings. ${ }^{16}$ Very pure indium could be obtained by electrorefining in organic electrolytes based on organoindium compounds, but these electrolytes are very difficult to handle because of their extreme air-sensitivity. ${ }^{16}$

\footnotetext{
${ }^{a}$ KU Leuven, Department of Materials Engineering, Kasteelpark Arenberg 44, bus 2450, B-3001 Heverlee, Belgium

${ }^{b}$ KU Leuven, Department of Chemistry, Celestijnenlaan 200F, bus 2404, B-3001 Heverlee, Belgium. E-mail: Koen.Binnemans@kuleuven.be

$\dagger$ Electronic supplementary information (ESI) available: Experimental methods, synthesis of electrolytes, cathodic current efficiency calculations using experimental EQCM data, EDS spectrum of deposits and images of the electrolytes. See DOI: $10.1039 / \mathrm{c} 8 \mathrm{cc} 10254 \mathrm{f}$
}

In this communication, the electrochemical behaviour and electrodeposition of indium from organic electrolytes composed of indium(III) chloride $\left(\mathrm{InCl}_{3}\right)$ and indium(III) bis(trifluoromethanosulfonyl)imide $\left(\operatorname{In}\left(\mathrm{Tf}_{2} \mathrm{~N}\right)_{3}\right)$ in 1,2-dimethoxyethane (DME, monoglyme) or poly(ethylene glycol) (average molecular mass of $0.400 \mathrm{~kg} \mathrm{~mol}^{-1}$, PEG400) is investigated. Glyme-based electrolytes exhibit desirable properties such as low viscosities, broad electrochemical windows and high thermal stabilities. Thus far, they have only been implemented in the development of electrolytes for lithium and magnesium batteries. ${ }^{16-20}$ The use of a mixture of two indium(III) salts, $\mathrm{InCl}_{3}$ and $\operatorname{In}\left(\mathrm{Tf}_{2} \mathrm{~N}\right)_{3}$, was inspired by the work on electrodeposition of magnesium, where $\mathrm{MgCl}_{2}$ was found to be poorly soluble in DME, but could be transformed into a highly soluble and electroactive species by the addition of $\mathrm{Mg}\left(\mathrm{Tf}_{2} \mathrm{~N}\right)_{2}{ }^{20}$

An electrolyte was prepared that was composed of DME, $0.4 \mathrm{~mol} \mathrm{dm}^{-3}$ of commercially available $\mathrm{InCl}_{3}$ and $0.4 \mathrm{~mol} \mathrm{dm}^{-3}$ of $\operatorname{In}\left(\mathrm{Tf}_{2} \mathrm{~N}\right)_{3}$ (details on the synthesis of this compound can be found in ESI $\dagger$ ). It was presumed that complexation occurred upon mixing the salts since $\mathrm{InCl}_{3}$ is poorly soluble in $\mathrm{DME}$, whereas the combination of $\operatorname{InCl}_{3}$ and $\operatorname{In}\left(\mathrm{Tf}_{2} \mathrm{~N}\right)_{3}$ resulted in fast quantitative dissolution.

Preceding the electrochemical characterization of the prepared electrolyte, the electrochemical window of DME was measured to determine the potential range of operation. As pure DME is not electrically conductive, $0.5 \mathrm{~mol} \mathrm{dm}^{-3}$ of carefully dried tetrabutylammonium tetrafluoroborate was added as an inert electrolyte. Tetra-alkylammonium salts are electrochemically very stable and are commonly used as supporting electrolyte in non-aqueous electrolytes. ${ }^{21}$ The measured electrochemical window of DME is shown in Fig. 1 (left axis, dashed line). The anodic limit of the solvent was found to be approximately $+2.0 \mathrm{~V} v s$. $\mathrm{Fc}^{+} / \mathrm{Fc}$, while the cathodic limit was at $-3.0 \mathrm{~V} v s . \mathrm{Fc}^{+} / \mathrm{Fc}$. A cyclic voltammogram (CV) of the prepared indium-containing electrolyte measured on a platinum-coated quartz crystal at room temperature is shown in Fig. 1 (left axis, full line). Distinctive, characteristic features for the electrodeposition and subsequent stripping of bulk metal were observed. The onset potential of the reduction current is positioned at 


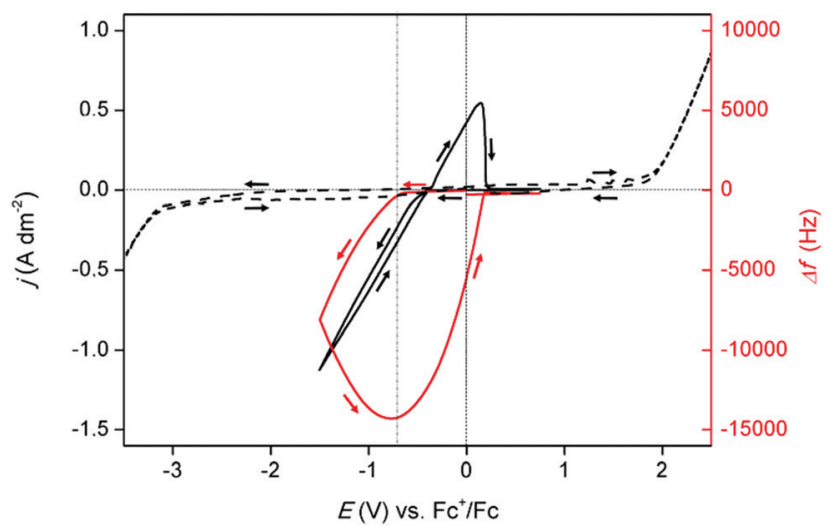

Fig. $1 \mathrm{CV}$ of $0.5 \mathrm{~mol} \mathrm{dm}^{-3}$ of tetrabutylammonium tetrafluoroborate in DME (dashed line, left axis) at a platinum electrode at a scan rate of $50 \mathrm{mV} \mathrm{s}^{-1}$, at room temperature and $\mathrm{CV}$ of $0.4 \mathrm{~mol} \mathrm{dm} \mathrm{dm}^{-3}$ of $\mathrm{InCl}_{3}$ and $0.4 \mathrm{~mol} \mathrm{dm}^{-3}$ of $\ln \left(\mathrm{Tf}_{2} \mathrm{~N}\right)_{3}$ in DME at a $5 \mathrm{MHz}$ platinum-coated quartz crystal at room temperature with a scan rate of $5 \mathrm{mV} \mathrm{s}^{-1}$ (full line left axis) with EQCM analysis (right axis).

$-0.4 \mathrm{~V} v s . \mathrm{Fc}^{+} / \mathrm{Fc}$, and is ascribed to the reduction of trivalent indium ions:

$$
\begin{gathered}
\mathrm{In}(\mathrm{III})+3 \mathrm{e}^{-} \rightleftharpoons \operatorname{In}(0) \quad E_{0}=-0.34 \mathrm{~V} \text { vs. SHE } \\
\mathrm{In}(\mathrm{III})+2 \mathrm{e}^{-} \rightleftharpoons \operatorname{In}(\mathrm{I}) \quad E_{0}=-0.44 \mathrm{~V} \text { vs. SHE } \\
\mathrm{In}(\mathrm{I})+\mathrm{e}^{-} \rightleftharpoons \operatorname{In}(0) \quad E_{0}=-0.14 \mathrm{~V} \text { vs. SHE }
\end{gathered}
$$

The absence of a limiting current indicates that this system is not mass-diffusion controlled. This points to a high mobility of the indium species towards the working electrode. After reversal of the scan direction, an anodic peak current was observed, which was attributed to stripping of the deposited indium.

Further insight into the mechanism of deposition and stripping of indium was obtained via a measurement with an electrochemical quartz crystal microbalance (EQCM). Herein, the frequency response, $\Delta f$, of the platinum-coated quartz crystal was monitored during the measurement of the CV (Fig. 1, right axis). The onset of the reduction current, at $-0.4 \mathrm{Vvs} . \mathrm{Fc}^{+} / \mathrm{Fc}$ in the forward scan, was not immediately accompanied by a change in the frequency signal. Hence, no deposition occurred. As DME is electrochemically stable, the occurring reduction process likely involved indium species. Indium(I) is an intermediate that has been described in various electrochemical studies. ${ }^{7,14}$ Furthermore, the standard reduction potentials of the $\operatorname{In}(\mathrm{III}) / \mathrm{In}(0)$ and In(III)/In(I) redox couples are close to each other: $-0.34 \mathrm{~V} v s$. SHE and $-0.44 \mathrm{~V} v s$. SHE, respectively. ${ }^{23}$ Therefore, it was assumed that the occurring process is the reduction from indium(III) to indium(I). Starting from $-0.7 \mathrm{~V} v s . \mathrm{Fc}^{+} / \mathrm{Fc}$ in the forward scan, a negative shift in the frequency signal was observed, indicating reduction of indium(III) to indium(0), and the reduction of indium(I) to indium(0). The largest shift, corresponding to the largest quantity of deposited indium, was reached at approximately $-0.7 \mathrm{~V} v s$. $\mathrm{Fc}^{+} / \mathrm{Fc}$ in the backward scan (indicated by the vertical dotted line). Between $-0.7 \mathrm{~V} v s . \mathrm{Fc}^{+} / \mathrm{Fc}$ and
$-0.4 \mathrm{~V}$ vs. $\mathrm{Fc}^{+} / \mathrm{Fc}$, the frequency shift is negative, meaning that the indium deposits dissolve, while the current in the CV is still negative. In this region, two reactions occur, namely, the reduction of indium(III) to indium(I), and the stripping of deposited indium to indium(I). The net total current due to both processes is negative. At potentials more positive than $-0.4 \mathrm{~V} v s . \mathrm{Fc}^{+} / \mathrm{Fc}$, the reduction of indium(III) to indium(I) no longer takes place but the oxidation of previously deposited indium to indium(I) continues, hence the current is positive. After the current falls to zero, a small negative $\Delta f$ remains, which implies that a quantity of unstripped indium is left on the crystal. Conceivably, indium forms alloys with the platinum electrode of the EQCM crystal, which are not oxidized in the imposed potential region. ${ }^{22}$ The cathodic current efficiency (CCE) of the deposition process was calculated by taking the ratio of the charge and equalled $114 \%$. Naturally this is an overestimation. (details regarding the calculation of the CCE and the explanation regarding the overestimation can be found in ESI, $\dagger$ together with an $m / z$ vs. potential plot, constructed using the presented EQCM data in Fig. 1).

To investigate the formation of indium(I) during reduction and oxidation, a rotating ring disk (RRDE) experiment was performed (Fig. 2). A CV was measured at room temperature at a slow scan rate of $5 \mathrm{mV} \mathrm{s}^{-1}$ on the gold disk, whereas a constant potential of $+1.0 \mathrm{~V} v s$. $\mathrm{Fc}^{+} / \mathrm{Fc}$ was applied on the gold ring, while rotating at $200 \mathrm{rpm}$. In principle, the indium(I) formed at the central disk is spun outwards towards the outer ring and subsequently oxidized to indium(III). It was observed that the ring current density ring immediately increased when the reduction current in the $\mathrm{CV}$ initiated, at $-0.7 \mathrm{~V} v s . \mathrm{Fc}^{+} / \mathrm{Fc}$, demonstrating the occurrence of the reduction of indium(III) to indium(I). Starting from $-0.9 \mathrm{~V} v s$. $\mathrm{Fc}^{+} / \mathrm{Fc}$ in the forward scan, increase in the current density on the ring gradually lessened. As the EQCM experiment suggested, at larger cathodic overpotentials, formed indium(I) further reduces to indium(0),

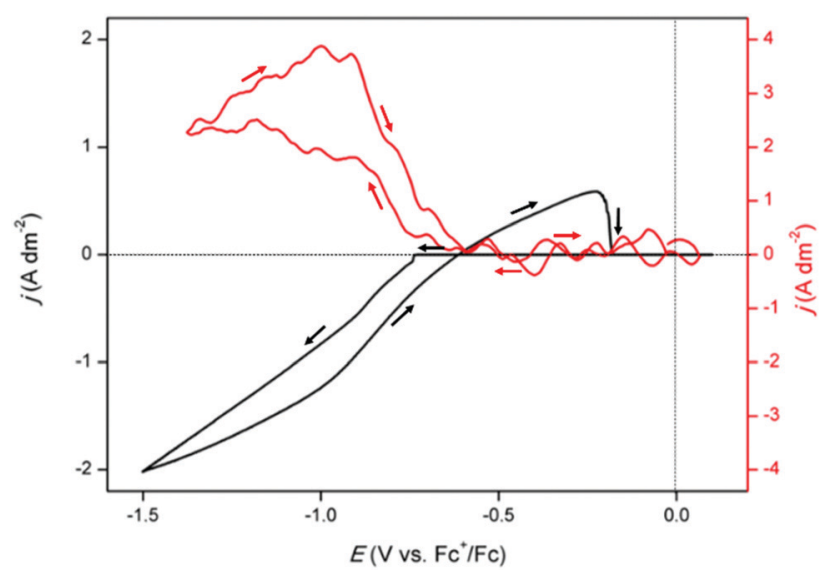

Fig. 2 Disk (left axis) and ring (right axis) currents recorded in $0.4 \mathrm{~mol} \mathrm{dm}^{-3}$ of $\mathrm{InCl}_{3}$ and $0.4 \mathrm{~mol} \mathrm{dm} \mathrm{m}^{-3}$ of $\operatorname{In}\left(\mathrm{Tf}_{2} \mathrm{~N}\right)_{3}$ in DME at $200 \mathrm{rpm}$ at room temperature. The disk current was generated from the cyclic voltammetry with a scan rate of $5 \mathrm{mV} \mathrm{s}^{-1}$, and the ring was kept at a potential of $+1.0 \mathrm{~V} \mathrm{vs}$. $\mathrm{Fc}^{+} / \mathrm{Fc}$. The ring current density data was smoothed by a Savitzky-Golay function with 40 points window size. 
forming deposits on the disk, and is therefore not spun outwards and captured on the ring. Between $-0.9 \mathrm{~V} v s . \mathrm{Fc}^{+} / \mathrm{Fc}$ and $-0.6 \mathrm{~V} v s . \mathrm{Fc}^{+} / \mathrm{Fc}$ in the backward scan, the ring current density starts to decrease. In this region, indium(I) is formed due to reduction of indium(III), and also due to oxidation of deposited indium. The net current of both processes is once more negative. However, the ring current completely drops to zero when the oxidation current in the CV initiates. Hence, no indium(I) if formed. It is postulated that the occurring processes during this oxidation current peak are oxidation of indium(I), formed during stripping, to indium(III), and possibly also stripping of remaining indium(0) to indium(III). It was observed that the solution colour slowly changed from pale yellow to black (see ESI $\dagger$ ). It has been demonstrated that indium(I) can undergo a disproportionation reaction: ${ }^{14}$

$$
3 \mathrm{In}(\mathrm{I}) \rightleftharpoons 2 \operatorname{In}(0)+\operatorname{In}(\mathrm{III})
$$

Here, the proceeding of reaction (4) likely leads to the formation of indium(0) nanoparticles stabilized by DME that serves as a capping agent, explaining the black colour.

The morphology and elemental composition of the indium deposits were studied by scanning electron microscopy (SEM) (Fig. 3). Indium was electrodeposited on a platinum plate at a constant potential of $-1.5 \mathrm{~V} v s . \mathrm{Fc}^{+} / \mathrm{Fc}$ for a period of $1 \mathrm{~h}$, at room temperature. The deposits were composed of rough shaped structures that fully covered the surface of the substrate (EDX spectrum is included in ESI $\dagger$ ).

An additional electrolyte was prepared that was composed of $0.4 \mathrm{~mol} \mathrm{dm}{ }^{-3}$ of $\operatorname{In}\left(\mathrm{Tf}_{2} \mathrm{~N}\right)_{3}$ and $0.4 \mathrm{~mol} \mathrm{dm}{ }^{-3}$ of $\mathrm{InCl}_{3}$ in PEG400. PEG400 has the advantage that it has a much higher boiling point $\left(290{ }^{\circ} \mathrm{C}\right)$ than DME $\left(85^{\circ} \mathrm{C}\right)$ so that PEG400 can be used for electrodeposition of indium above its melting point $\left(156.6{ }^{\circ} \mathrm{C}\right)$. Fig. 4a shows the CV of the PEG400 electrolyte, recorded on a platinum-coated quartz crystal at $100{ }^{\circ} \mathrm{C}$ with EQCM analysis. It was observed that the onset of the reduction current, at $-0.27 \mathrm{~V}$ vs. $\mathrm{Fc}^{+} / \mathrm{Fc}$ in the forward scan, was not immediately accompanied by a change in frequency. Most probably, the reduction of indium(III) to indium(I), and the subsequent disproportionation to indium(III) and indium(0) nanoparticles, occurred in this potential region. From $-0.9 \mathrm{~V} v s . \mathrm{Fc}^{+} / \mathrm{Fc}$ in the

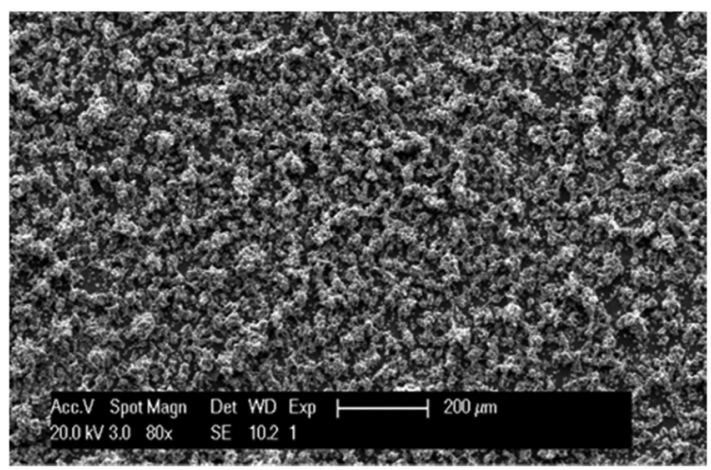

Fig. 3 SEM image of indium deposited on a platinum working electrode at $-1.5 \mathrm{~V}$ vs. $\mathrm{Fc}^{+} / \mathrm{Fc}$ at room temperature for $1 \mathrm{~h}$ from $0.4 \mathrm{~mol} \mathrm{dm}^{-3}$ of $\ln \left(\mathrm{Tf}_{2} \mathrm{~N}\right)_{3}$ and $0.4 \mathrm{~mol} \mathrm{dm}{ }^{-3}$ of $\mathrm{InCl}_{3}$ in DME.
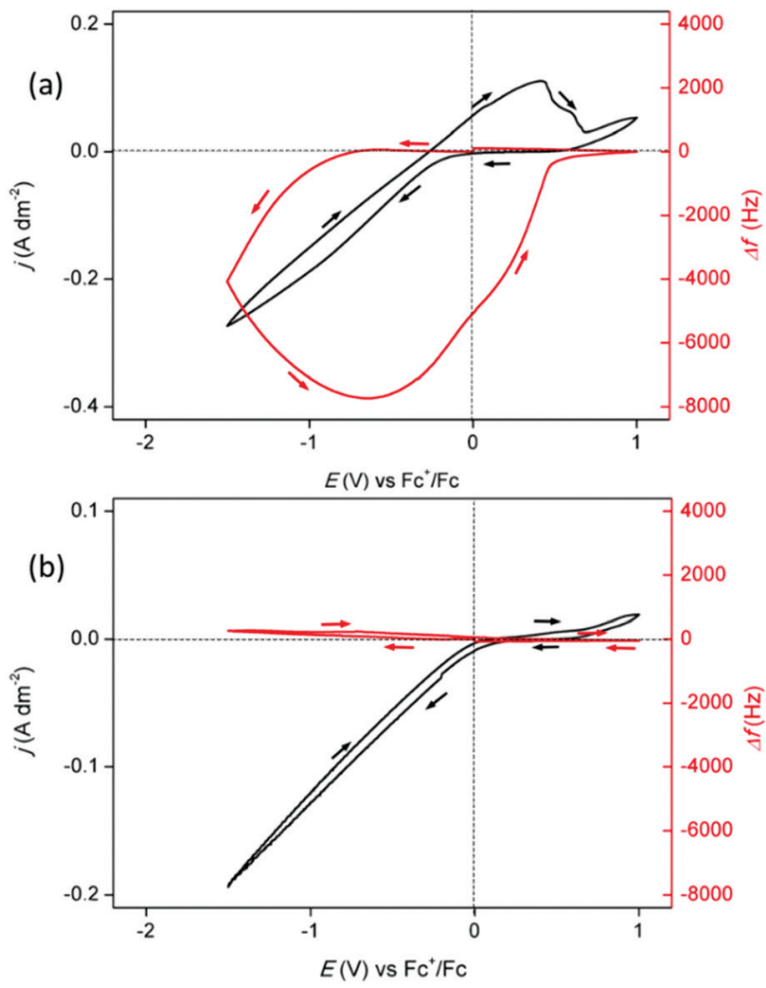

Fig. 4 (a) $\mathrm{CV}$ of $0.4 \mathrm{~mol} \mathrm{dm} \mathrm{m}^{-3}$ of $\operatorname{In}\left(\mathrm{Tf}_{2} \mathrm{~N}\right)_{3}$ and $0.4 \mathrm{~mol} \mathrm{dm} \mathrm{m}^{-3}$ of $\mathrm{InCl}_{3}$ in PEG400 at a $5 \mathrm{MHz}$ platinum-coated quartz crystal at $100{ }^{\circ} \mathrm{C}$ with a scan rate of $50 \mathrm{mV} \mathrm{s}^{-1}$ (left axis) with EQCM analysis (right axis). (b) $\mathrm{CV}$ of $0.4 \mathrm{~mol} \mathrm{dm}^{-3}$ of $\operatorname{In}\left(\mathrm{Tf}_{2} \mathrm{~N}\right)_{3}$ and $0.4 \mathrm{~mol} \mathrm{dm}^{-3}$ of $\mathrm{InCl}_{3}$ in PEG400 at a $5 \mathrm{MHz}$ platinum-coated quartz crystal at $160{ }^{\circ} \mathrm{C}$ with a scan rate of $50 \mathrm{mV} \mathrm{s}^{-1}$ (left axis) with EQCM analysis (right axis).

forward scan to $-0.65 \mathrm{~V}$ vs. $\mathrm{Fc}^{+} / \mathrm{Fc}$ in the backward scan, a significant negative shift in the frequency signal appeared, indicating the deposition of indium. Accumulation of the anodic current, starting from $-0.65 \mathrm{~V}$ vs. $\mathrm{Fc}^{+} / \mathrm{Fc}$ in the backward scan, led to a positive shift in the frequency signal, indicating the stripping of deposited indium. The small increase in current which arises after the stripping wave was attributed to the anodic decomposition of PEG400 (the electrochemical window of PEG400 is included in ESI $\dagger$ ). The cathodic current efficiency of the deposition process was calculated and equalled $81 \%$.

Fig. 4b shows the CV of the PEG400 electrolyte, recorded on a platinum-coated quartz crystal at $160{ }^{\circ} \mathrm{C}$ with EQCM analysis. A noteworthy reduction current was observed from $0.0 \mathrm{~V} v s$. $\mathrm{Fc}^{+} / \mathrm{Fc}$ in the forward scan to $0.0 \mathrm{~V} v s . \mathrm{Fc}^{+} / \mathrm{Fc}$ in the backward scan, yet the frequency signal remained nearly stagnant. Hence, negligible deposition takes place throughout the reduction wave. Therefore, the main occurring process is the reduction of indium(III) to indium(I). No anodic current is observed as no indium is deposited and indium(I) disproportionates to indium(III) and indium(0) nanoparticles. It was observed that the colour of the electrolyte darkened throughout the measurement. This was attributed to the formation of nanoparticles. To verify their formation, the spent, black electrolyte was collected after the measurement. It was diluted with acetone and dried on a 300 mesh Formvar/carbon coated copper grid. Analysis using 


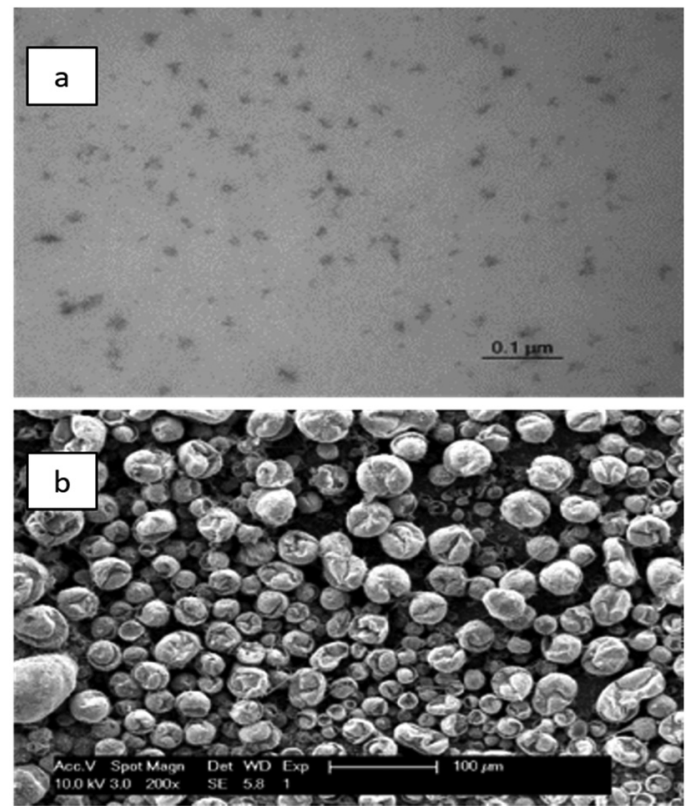

Fig. 5 (a) TEM image of indium nanoparticles, formed during recording of a CV of $0.4 \mathrm{~mol} \mathrm{dm}^{-3}$ of $\ln \left(\mathrm{Tf}_{2} \mathrm{~N}\right)_{3}$ and $0.4 \mathrm{~mol} \mathrm{dm}^{-3}$ of $\operatorname{lnCl}_{3}$ in PEG400, at $160{ }^{\circ} \mathrm{C}$, on a molybdenum electrode. (b) SEM image of indium deposits on a molybdenum electrode at $-1.0 \mathrm{~A} \mathrm{dm}^{-2}$ for $1 \mathrm{~h}$.

transmission electron microscopy (TEM) indicated the presence of irregularly shaped agglomerates of indium nanoparticles (Fig. 5a).

Fig. 5b shows a SEM micrograph of indium deposits obtained by applying a high constant current of $-1.0 \mathrm{~A} \mathrm{dm}^{-2}$ for $1 \mathrm{~h}$ at $160{ }^{\circ} \mathrm{C}$, on a molybdenum electrode. Besides nanoparticles, a small amount of spherical indium particles were obtained that are dimpled on their surface. These indium droplets become dimpled during solidification of the molten indium upon cooling because of the change in density.

In conclusion, the electrochemical behaviour of indium(III) in DME and PEG400 was investigated at room temperature and $160{ }^{\circ} \mathrm{C}$, respectively. It is postulated that mixing both $\mathrm{InCl}_{3}$ and $\operatorname{In}\left(\mathrm{Tf}_{2} \mathrm{~N}\right)_{3}$ salts in the organic solvents leads to the formation of an electroactive complex. During reduction, both the reduction from indium(III) to indium(0) and from indium(III) to indium(I) was demonstrated. Indium(I) subsequently reacts to indium(III) and indium(0) through a disproportionation reaction. Indium(0) species in solution agglomerate forming nanoparticles. SEM analysis showed rough deposits from the DME-based electrolyte at room temperature, whereas spherical deposits were obtained from the PEG400 electrolyte at $160{ }^{\circ} \mathrm{C}$. The observations that $\mathrm{MgCl}_{2}+\mathrm{Mg}\left(\mathrm{Tf}_{2} \mathrm{~N}\right)_{2}$ can be used for electrodeposition of magnesium ${ }^{20}$ and $\operatorname{InCl}_{3}+\operatorname{In}\left(\mathrm{Tf}_{2} \mathrm{~N}\right)_{3}$ for electrodeposition of indium suggest that $\mathrm{MCl}_{x}+\mathrm{M}\left(\mathrm{Tf}_{2} \mathrm{~N}\right)_{x}$ are versatile electrolytes for electrodeposition of metals that cannot be obtained from aqueous electrolytes, or only with poor current efficiency.

The authors acknowledge financial support from the European Research Council (ERC) under the European Union's Horizon 2020 Research and Innovation Programme: Grant Agreement 694078-Solvometallurgy for critical metals (SOLCRIMET).

\section{Conflicts of interest}

There are no conflicts to declare.

\section{Notes and references}

1 U. Schwarz-Schampera and P. M. Herzig, Indium: Geology, mineralogy, and economics, Springer Science \& Business Media, 2002.

2 F. Ullmann, W. Gerhartz, Y. S. Yamamoto, F. T. Campbell, R. Pfefferkorn and J. F. Rounsaville, Ullmann's encyclopedia of industrial chemistry, VCH publishers, 1985.

3 F. C. Walsh and D. R. Gabe, Surf. Technol., 1979, 8, 87-99.

4 Y. Traore, S. Legeai, S. Diliberto, G. Arrachart, S. Pellet-Rostaing and M. Draye, Electrochim. Acta, 2011, 58, 532-540.

5 R. Piercy and N. A. Hampson, J. Appl. Electrochem., 1975, 5, 1-15.

6 M. Yang and I. Sun, J. Chin. Biochem. Soc., 2004, 51, 253-260.

7 J. Estager, P. Nockemann, K. R. Seddon, G. Srinivasan and M. Swadźba-Kwaśny, ChemSusChem, 2012, 5, 117-124.

8 M. Matsumiya, M. Sumi, Y. Uchino and I. Yanagi, Sep. Purif. Technol., 2018, 201, 25-29.

9 S. Z. El Abedin, A. Y. Saad, H. K. Farag, N. Borisenko, Q. X. Liu and F. Endres, Electrochim. Acta, 2007, 52, 2746-2754.

10 E. Barrado, S. García, J. A. Rodriguez and Y. Castrillejo, J. Electroanal. Chem., 2018, 823, 106-120.

11 J. C. Malaquias, M. Steichen, M. Thomassey and P. J. Dale, Electrochim. Acta, 2013, 103, 15-22.

12 M. F. Rahman, R. Bernasconi and L. Magagnin, J. Optoelectron. Adv. Mater., 2015, 17, 122-126.

13 A. A. C. Alcanfor, L. P. M. dos Santos, D. F. Dias, A. N. Correia and P. de Lima-Neto, Electrochim. Acta, 2017, 235, 553-560.

14 M. K. Carpenter and M. W. Verbrugge, J. Mater. Res., 1994, 9, 2584-2591.

15 U. Anders and J. A. Plambeck, Can. J. Chem., 1969, 47, 3055-3060.

16 P. N. Bartlett, D. Cook, C. H. K. de Groot, A. L. Hector, R. Huang, A. Jolleys, G. P. Kissling, W. Levason, S. J. Pearce and G. Reid, RSC Adv., 2013, 3, 15645-15654.

17 R. E. Doe, R. Han, J. Hwang, A. J. Gmitter, I. Shterenberg, H. D. Yoo, N. Pour and D. Aurbach, Chem. Commun., 2014, 50, 243-245.

18 D. Sharon, D. Hirshberg, M. Afri, A. A. Frimer and D. Aurbach, Chem. Commun., 2017, 53, 3269-3272.

19 S. A. Freunberger, Y. Chen, N. E. Drewett, L. J. Hardwick, F. Bardé and P. G. Bruce, Angew. Chem., Int. Ed., 2011, 50, 8609-8613.

20 Y. Cheng, R. M. Stolley, K. S. Han, Y. Shao, B. W. Arey, N. M. Washton, K. T. Mueller, M. L. Helm, V. L. Sprenkle and J. Liu, Phys. Chem. Chem. Phys., 2015, 17, 13307-13314.

21 H. O. House, E. Feng and N. P. Peet, J. Org. Chem., 1971, 36, 2371-2375.

22 W. G. Moffatt, The Handbook of Binary Phase Diagrams, General Electric Company, Corporate Research and Development, Technology Marketing Operation, 1981.

23 W. M. Haynes, CRC handbook of chemistry and physics, CRC press, Boca Raton, 92nd edn, 2011. 